\title{
Local Cleavages, Politics and Policy at the Local Level - Is the Depolitization Real? ${ }^{1}$
}

\author{
Sta nisla v Ba lík
}

\begin{abstract}
The aim of this article is to identify gaps in considering local self-government as an inherently primarily non-political or anti-political area. The concept of local cleavages, which is based on the theory of cleavages of Stein Rokkan and Seymour M. Lipset, is then presented. The author shows eleven potential cleavages which can be observed in Czech local politics. Six of them are clearly based on the local level: the development contradiction, the origin contradiction, the geographic contradiction, the clubs contradiction, the citizen vs. community contradiction, the contradiction about the extent of functions of the municipality. Another four cleavages are derived from the national level: religious cleavage, socialeconomic cleavage, the post-materialism cleavage, cleavage related to legacies of the old regime. The final one shares the logic of those at the national level, but doesn't fit the Lipset and Rokkan model: namely, the gender contradiction. The article shows that politics has disappeared from the local level only in a declaratory way but not in reality. Under various labels such as independency, non-partisanship and expertness, the illusion of non-interest is created and maintained. However, local policy is not without interests; in fact, it is a political area in every sense of the word.
\end{abstract}

KEYWORDS local self-government, local policy, local cleavages, Czech Republic

\section{Introduction}

Where public power enters individual human lives and interpersonal relationships, politics is also immediately present. Therefore, it is not only VAT or property tax disputes that are political but also disputes regarding home birth, mandatory infant vaccination or ways of collecting fees for communal waste disposal.

The goal of this article is to first identify the problematic aspects of considering local self-government as an inherently and primarily non-political or even anti-political area. Then, based on Lipset and Rokkan's (1967) cleavage theory, the concept of local cleavages will be introduced. Local cleavages help both to explain the logic of many local political clashes (the politics dimension) and rehabilitate the idea of the real political character of even the lowest level of Czech self-government (in the sense of policy).

Sociální studia / Social Studies 1/2016. Pp. 73-85. ISSN 1214-813X.

1 This text was prepared with support from the Czech Science Foundation grant project No. 15-22754S “Kvalita demokracie: Česká republika v komparativní perspective” (Quality of Democracy: Czech Republic in the Comparative Perspective). 
This topic is not completely new. The author of this article hinted at it in some of his previous texts (Balík 2004, 2009). Additionally, local conflicts in small municipalities are examined mainly by researchers from the Česká zemědělská univerzita [Czech University of Life Sciences] (cf. above all Bubeníček and Kubálek 2010; Kubálek and Bubeníček 2012; Bubeníček 2009; Čopík 2013; Čmejrek, Bubeníček and Čopík 2010; Čmejrek 2005; Čmejrek 2008; Čmejrek 2013).

The terms "party" or "partisan" used in this paper are used in the instrumental sense of the word - i.e., they also cover political movements or local associations of independent candidates.

\section{Non-political local politics?}

When considering the disappearance of politics in the Czech Republic, it is interesting to think about local politics because this is where the beginning of the whole phenomenon can be identified. It is not necessary to support this statement by data about the decline of political partisanship at the local level, despite the fact that the data are rather telling (e.g. in 1994, $25.2 \%$ of elected representatives were members of some political party whereas twenty years later it was only $11.7 \%$; in 1994, candidates who were members of a political party accounted for $35.5 \%$ of all candidates whereas in 2014 it was only $15.9 \%$ (cf. Volby.cz 2015). What is more important, though, is the fact that many local politicians, including those who are members of political parties represented in parliament, refuse to regard themselves as politicians, thus indirectly helping to significantly narrow the concept of politics to the national level only. They utilize many analogies from their everyday lives where they apparently have to look after citizens and their municipalities rather than "do politics" - pavements are apparently neither right-wing nor left-wing, sanitation and playgrounds are constructed by both right-wing as well as left-wing parties (for more information cf. Ryšavý 2006: 953-954).

There are two underlying reasons for such thinking. One of them is the fact that political conflict has been mistakenly narrowed down to a conflict of the right and left, i.e. to the socio-economic conflict (for more on why "mistakenly," see below). The second, an even more potent cause, is the idea that the one correct solution for each problem and situation can be found somewhere (an attitude perhaps similar to Plato's "Realm of Forms" of technocrats). Within this perception, the goal of the mayor or local representatives is to attempt to discover such solutions, grasp them as correctly as possible and implement them. The discourse that can be observed not only prior to local elections, but basically in any municipality, seems to show that the local politicians-nonpoliticians really believe this. Such thinking chases politics - politics as a discussion, a dispute, a clash or a conflict - away. Why discuss and argue if the only possible correct solution exists somewhere? Arguments and conflicts only break the desired unity and so away with them (away with politics). Additionally, this issue is closely linked with the idea of "being an expert" as an opposing quality of "being a politician" (however, high-level politics is most likely to blame for this).

After all, the categories of politicians and experts (officials) are perceived as mutually exclusive at the national level and sometimes questions are raised as to under which circumstances the knowledge of experts should be favoured as opposed to the will of partisan 
(political) bodies, and when, on the contrary, the expert point of view needs to be confronted with the democratic process and the majority point of view (Pribán 2014: 49). The example of the significant popularity of multiple post-November so-called "caretaker governments" shows the dangerous tendency to "understand the de-politized government as an expert idyll, which is able not only to govern better than the constantly bickering political parties but also to resolve every single political problem through expertise" (Přibáň 2014: 53); in other words, it reveals an a priori trust in experts and an a priori distrust of politicians. The paradoxical specialty of the Czech local reality is the fact that the elected representatives-politicians like to assume the role of the experts and do not want to be regarded as politicians.

The fundamental problem of such thinking is that a single correct solution usually does not exist, or rather, does not exist in a democracy, an arena where different interests compete with each other. One of the biggest Czech democracy theorists, Vladimír Čermák, even connects democracy inseparably with the term "contention" (polemos). He understands polemos as the only possible way of resolving the issue of the internal and external deficiencies of man, as the only means of giving a meaning and drama to life. "As long as a man will be a man, there will also be a polemos" (Fiala and Mikš 2000: 90-91). By connecting what is natural to humans with the natural characteristics of democracy he supports his proposition about the natural human tendency to say yes to democracy and to reject non-democracy.

In the narrower sense of the word, a polemos means a social conflict in a society, where power, an estate, is at stake. Thus, wherever conflict is present in a public space, politics is also present. If we look at the question of the political character of local self-government from this perspective, new possibilities open. If we understand the competition of interests and social conflict as a polemos, and therefore also as an actual means of "doing politics", we can see that there are political debates and decisions at even the lowest level, in other words that almost every decision is the result of some conflict of interests. Therefore, a difference of opinion about the support of local sport and cultural organizations is also a political conflict. Of course, purely technocratic questions do exist as well - very often, local self-governments have to respond to requirements imposed by the state administration (e.g. should a street be reconstructed, it must meet technical norms and a debate is therefore, in principle, pointless).

Resistance against politics contains a latent desire for unity and peace. The general public expects that expert governments, by ceasing to burden society with endless debates and conflicts, will ensure these values. However, the desire for unity and peace goes directly against the principle of democracy, which will not ensure them but is able to name and tackle its own crises instead (Přibáň 2014: 54).

The desire for unity is even more powerful at the local level. The resistance to a competition, conflict and discord is often (most of the time?) predominant (in other words, the Gemeinschaft approach dominates - see below). In the municipality of Vikýřovice, for example, an Association of Independent Candidates called "For the Unity of Citizens" won among eleven candidate parties applying for fifteen mandates (it got six mandates) (Volby.cz 2015). It seems that the Association satisfied the predominant desire of people living in the society full of conflicts with its name itself.

The technical nature of many problems to be solved certainly does contribute to the denial of the political character of local self-government: e.g. the development of civil infrastructure, 
insulation of buildings, repair of local roads. This situation is rather extreme at the level of administrative units ( $k r a j)$, which have been entrusted with the administration and development of mainly infrastructure areas (e.g. transportation, secondary schools, health care). It is likely that the "expert" and no-conflict nature of these areas has caused - as the poll prior to district elections in 2012 showed - there to be a lot of unity regarding the actual topics as well as their solutions among individual candidates (cf. Eibl, Gregor and Macková 2013: 71-78). In this context, a question arises whether the district level (kraje), with its current scope of competences, should be a self-governing level, but this goes beyond the scope of this paper.

\section{Cleavages}

The fundamental lack of understanding in thinking about the political nature of local selfgovernment also stems from the fact that the term "politics" has been almost exclusively identified with left-wing/right-wing conflict. However, at least since Stein Rokkan and Seymour Martin Lipset, it has been known that the cleavage of politics in not the only socioeconomic contradiction which corresponds with the current perception of the right-wing and left-wing clash, nor is politics the oldest one. Before going back to local politics, let us briefly remind ourselves of Rokkan and Lipset's theory of cleavages (for full argumentation cf. Lipset and Rokkan 1967).

Cleavages are the result of two significant historical processes which have transformed Europe in recent centuries - the national and industrial revolutions. The national revolution amplified the process of nation-building. Its most well-known outcomes are: the establishment of modern nations and national identities, language unification and the establishment of military-administrative, economic and cultural centres. However, this process wasn't simple. Regions frequently opposed such efforts because they had different identities than the centre (reasons for this varied; they were historical, ethnic and language related). This can be illustrated by the example of France before the 1789 revolution, Spain, etc. The national revolution brought a big contradiction between the centre and the periphery.

Simultaneously, large conflicts between Catholicism and Protestantism took place and absolutist states put a great effort into restricting the power and influence of the Church in society, or rather to impose state surveillance on it. The Church and its representatives opposed such efforts. In the $19^{\text {th }}$ and $20^{\text {th }}$ centuries, the transformative phenomenon of secularization joined this mix, which gave rise to a potent contradiction between towns and countryside.

The industrial revolution changed the character of the economy, which has been based primarily on private capitalistic entrepreneurship and wage labour since the industrial revolution started. It is the contradiction of these two categories - capital versus labour - that formed the most significant social cleavage until the present, and which gave rise to the widespread Marxist revolutionary movement and has influenced the main direction of political debates until these days.

During the second half of the $20^{\text {th }}$ century, the influence of post-materialist themes grew. These themes are not about economic contradictions but contradictions of values priorities themes such as gay rights, abortion and protection of the environment enter the scene. 
Another cleavage appeared after the fall of the communist regimes in Central and Eastern Europe - communism versus anti-communism. However, this contradiction could be considered, more generally, as a cleavage in relation to the old regime. There are many similar examples of such cleavages (not only in relation to the communist regime) in European societies and they relate to any regime-related change: e.g. after the French Revolution, after the Bourbon restoration, after the rise and fall of the second French empire, after the postWorld War I decline of monarchies in Central Europe, etc.

Individual cleavages also interact with each other, a type known as cross-cutting cleavages. Such cross-cutting differences can strengthen individual cleavages but it can also neutralize them.

Based on cross-cutting cleavages, various political parties were established, depending on the bonds between parties and their electoral segments. The centre-periphery cleavage gave rise to many regional formations ("parties of territorial protection"); the state-church cleavage produced Christian-democratic and Christian-socialist parties; the town-countryside cleavage was behind the establishment of agrarian parties; the owners-workers cleavage supported the creation of social-democratic and socialistic parties. All these parties stood against the urban conservative and liberal elites that had been dominant until then. The post-materialism cleavage formed green parties, and the cleavage in relations to the old regime gave rise to various formations during transition phases as well, as can be seen, for instance, in current communist parties (for details cf. Hloušek and Kopeček 2004: 34-54).

Thus, we can observe six cleavages (four "classical ones", plus one post-materialism cleavage and one related to the old regime, of which only one (although admittedly a dominant one) relates to what we refer to as the "right wing" and the "left wing". Political clashes have, and can have, many dimensions - at the national level as well as the local level.

Of these six nationwide cleavages, all six of them can appear in political communities, although, admittedly, with different levels of likelihood and intensity. These are accompanied by other cleavages, which are mainly linked to the local level.

\section{The Gemeinschaft vs. Gesellsc haft meta-contradiction}

Above individual cleavages, which are either transformed from the national level or are of specifically local character, can be observed yet another, higher contradiction - almost a meta-contradiction - that rises above individual cleavages and overlaps with many of them. This contradiction has obviously significant political consequences.

It is the dichotomy of the Gemeinschaft (community) and Gesellschaft (society) concepts introduced by German sociologist Ferdinand Tönnies at the end of the $19^{\text {th }}$ century. Gemeinschaft refers to a municipality (which is determined not just at a territorial level but also on a personal level) as a community formed by the attitudes of peasants and townsmen, which influence further self-identification of the municipality. This is a more collectivistic concept, based on neighbourhood relations.

Its antithesis is the individualistic and rationalistic modernism referred to as Gesellschaft (characterized by utilitarianism and calculation); emphasis on performance and efficiency is also loosely associated with this notion, and it is no coincidence that this term is also used to 
refer to a corporation in German (cf. Burrow 2003: 136). A society (Gesellschaft) is, in this sense, characterized by the following values: egotism, competition, profit and instrumental rationality.

Both positions can be aptly described as emotionality (Gemeinschaft) and rationality (Gesellschaft), respectively. Although this division may seem ideal-typical at best, or even purely theoretical and without any impact on practical (local) politics, it is not so. The cleavage is reflected in many everyday debates either latently or without any awareness altogether.

In order to better understand the differences between these two notions, it may be useful to apply them to the national level where, (at least) in continental Europe, the nation and the state, i.e. national identity and citizenship of a state, are distinguished. The concept of the nation is based on Gemeinschaft (often an irrational or an emotional feeling of closeness, common roots, culture, etc., which should give rise to certain commitments), whereas the concept of the state (citizenship) is based on Gesellschaft (in a way rational, albeit possibly a random group of citizens sharing a defined geographical space). At the municipality level, this distinction would be best expressed by the terms "old residents of the municipality" (the feeling of connection, closeness) versus "citizens of the municipality" (undifferentiated).

Both concepts are present in the legal definition of a municipality, whereby a municipality is understood as the lowest organizational territorial unit, a community of its inhabitants: "A municipality is the fundamental territorial self-governmental community of citizens; it forms a territorial unit which is delineated by the municipality's border. The municipality is a public service corporation..." (Act No. 228/2000 Coll. $\S \S 1-2$ ). Thus, it has an organizational as well as a personal-communal character. This contradiction - i.e., debate over which is superior: an organisational and territorial unit or a community (communality) of people? - remains an aspect of the Czech local sphere even today. It resonates both during election campaigns as well as during local authorities' meetings and general debates about political participation, and, as an undertone, when forming general or broad coalitions. Terms such as effectiveness of local self-government and its decision-making processes, rationality and advantageousness are contrasted with terms such as mutual help, duty and responsibility towards the municipality, etc.

Let us remember, as a side note, that the division into Gemeinschaft and Gesellschaft is ideal-typical; both approaches often mix and clash, and not only within one political group but even within the mind-set of an individual.

Neither of these approaches is "correct" on its own - they are political in every sense of the word, dependent on underlying values. Both approaches are absolutely legitimate and they cannot be decided "technically". Those who hold to one will be convinced of its appropriateness (and the inappropriateness of the other). ${ }^{2}$

The Gemeinschaft approach argues emotionally (paradoxically, it loves technical and generally correct solutions at the same time), which can be to its advantage as well as to its disadvantage; in any case, emotionalism is its inherent component, one of its defining features. In a sense, it can be understood as conservative but only to a point. This "municipal

2 For specific examples of conflicts between the supporters of these approaches, cf. Balík (2009: 219-221). 
conservatism" does not necessarily imply a conservative view of other aspects of social life e.g. the role of religion in society, social and economic relations, etc. Gemeinschaft also tends to dislike any conflict, which is something that does not belong in a "family" (which is how it perceives the municipality). In contrast, Gesellschaft supporters believe that competition between interests animates and injects real life into politics and the public sphere.

Disagreements related to the political character of local self-government can therefore be sometimes perceived as a clash between Gemeinschaft supporters (who value non-political character, unity and conflict avoidance) and Gesellschaft supporters (who emphasize competition). However, it needs to be pointed out that this is a meta-contradiction which overlaps with many lower-level conflicts. It can happen quite easily that two Gemeinschaft supporters will disagree because their attitudes towards various "lower-level" issues will correspond with other cleavages, or even the same one but its opposite sides.

\section{Local cleavages}

Based on the author's research of local politics as well as his search through primary sources and the relevant secondary literature, eleven potential political contradictions that can be observed in Czech local politics have been identified. Not all of them are present in each and every municipality. What is presented is more of a catalogue of potential cleavages. They differ in significance and importance and their potency can also vary depending on a municipality.

The following six cleavages are clearly anchored at the local level: a) the development contradiction, b) the origin contradiction, c) the geographic contradiction, d) the clubs contradiction, e) the citizen versus community contradiction, f) the extent of the functions of the municipality contradiction. Four cleavages derived from the national level are: g) the religious contradiction, h) the labour versus capital contradiction, i) the post-materialism contradiction, j) the contradiction related to the relations with the old regime. Finally, one of a national level character which, however, does not correspond with Rokkan's concept of cleavages: $\mathrm{k}$ ) the gender contradiction.

Based on these eleven possible cleavages, it is possible to understand the logic of the majority of conflicts at the local level (if we ignore purely personal logic, of course - personal closeness or, as the case may be, personal as well as family animosities). The abovementioned note about the possibility of cross-cutting cleavage also applies here, which can lead to enhancement or elimination of the effect.

Furthermore, not every type of cleavage qualifies as such in every municipality. Some cleavages take the form of a short-term conflict and do not give rise to any long-term "political" subject, which is the core idea of Rokkan's model. Nevertheless, each contradiction can permanently impact the structure of the local political community under certain conditions. Let us have a look at the individual types of cleavage in greater detail:

a) The development contradiction - This is a very common contradiction, present in particular in smaller, "developer-oriented" municipalities. It often relates to the degree of development: to what extent should the municipality grow and modernize its facilities 
and to what extent should it remain "a museum" or an ordinary municipality (Foltánková and Fajkusová 2014)? Contrasting opinions are usually varied: give a green light to the development of new houses or not build anything; should there be municipality-driven support for construction (infrastructure development) or should the costs be paid individually (cf. Balík 2009: 225-226); should entertainment parks be developed (either by the municipality or by a private investor approved by the municipality) or should such projects be regulated? Should the municipality create new job opportunities but lose its peaceful and picturesque character? This cleavage partially overlaps with the main Gemeinschaft-Gesellschaft meta-contradiction, but not always. These don't have to be conflicts between developers and old residents, but a vision conflict: should municipalities be primarily good places for the local inhabitants or should they be primarily an attractive tourist destination? Such conflicts translate into reflections on the priorities of investment actions, the appropriateness or extent of municipal debt, etc.

b) The origin contradiction - This contradiction is evident in all municipalities but it becomes more potent when the municipality grows quickly. It can also be labelled "the old residents versus newcomers" contradiction. It can have several faces. One of them is the conflict between those who were born in the municipality and those who moved there as adults. This is the least sharp contradiction (and cannot even be considered a cleavage as such). In this case, there is a majority of old residents and just a handful of newcomers. Such a distinction has more of a personal than group character. ${ }^{3}$ The more serious cleavage is a group contradiction - this is the case of municipalities that rapidly grow in size within a short period of time (there are many such municipalities in the Czech Republic where the number of inhabitants quadrupled within 10 years due to residential housing development). It can happen that the newcomers are not happy with the work of the local authorities and thanks to their large numbers outvote the old residents - this can be illustrated by the municipality of Velké Prrílepy (in the Prague-West district) (Čmejrek, Bubeníček and Čopík 2010: 129). There is also a specific variation of a contradiction between old residents and weekend-house owners in many low-population municipalities. However, this contradiction is rarely about adherence to a party since the weekend-house owners usually don't have permanent residence in the municipality. Nevertheless, debate over which criteria should be used in determining fees for communal waste collection, for example, can have such consequences. There is also the paradoxical situation where the community is "kept alive" thanks to the weekend-house owners rather than the old residents (Bubeníček and Kubálek 2010: 32).

c) The geographic contradiction - There are two basic varieties of this contradiction. Both can be observed in municipalities comprising several settlement units with their own identities and that were independent municipalities several decades ago. In cases of similar, village-type units, the centre versus periphery contradiction can be observed, when the not-so-large centre of the municipality is accused by people from peripheral

However, it must be noted that not much may change for the newcomers despite their pressure. For the rest of their lives they may never be accepted by the old residents as legitimate inhabitants, and will always be perceived as "incomers," "strangers," etc. 
areas of neglecting the periphery and favouring the centre itself. If the centre has a town character and the adjacent parts are independent villages, this conflict is also coloured by the town-versus-countryside contradiction. This situation can be enhanced by dividing the municipality into electoral units (not districts) respecting the geographic logic of the local parts (this can be illustrated, for example, by the municipality of Lišov in the České Budějovice district Město Lišov).

d) The clubs contradiction - In many municipalities and towns the club-based contradiction can be observed. In its simplest form, this is conflict between cultural and sport organizations and differing degrees of support for them from municipal bodies (not necessarily solely financial support). However, sport clubs can also stand against each other, e.g. performance-oriented clubs versus recreation-oriented clubs; or, alternatively, conflict can be observed between two performance-oriented clubs (an athletic club against a football or ice-hockey club, for instance), two cultural clubs (e.g. an amateur theatre versus a choir), or between two children's clubs (e.g. the conflict between football and ice-hockey interests in Nedvědice leading to the closure of the winter stadium [Vejrosta 2014: 2-3]). Such competition plays a role in setting the municipality's investment priorities, permitting various events in public spaces, etc. (This conflict was particularly strong before World War I and during the interwar years in the Orel versus Sokol clash and the Orel versus Národní jednota clash, etc. - compare, for instance, with the political conflict regarding cinema licencing in Žarošice between the wars [Vachová 2010: 63]). Theoretically, a conflict is also possible between municipal clubs, each of which require special treatment and give certain advantages, and citizens who are not involved in any clubs at all.

e) The citizen versus community contradiction - This contradiction is about what comes first - the community or the rights and interests of individuals? Most of the time the priority is clear and the situations to be tackled are not complicated. However, there are occasions when community interests conflict with individual interests. One example can be seen in conflicts about the development of line constructions (e.g. ring roads, pavements, etc.) against the will of landowners (cf. e.g. Balík 2009: 225-226); another is conflicts arising during negotiations about changes in land use and zoning plans which would limit the expansion of an individual's business which threatens to negatively impact the community character for others.

f) The contradiction about the extent of municipality functions - This contradiction is analogical with the national level conflict over the extent to which the state (municipality) can interfere with an individual's life. What should the citizen deal with himself and what should be tackled by a corporation such a municipality? Should the municipality organize cultural events, or should they result from the spontaneous activity of citizens associated in clubs? Should the municipality determine a day when work with noisy tools and instruments is banned? What services should the municipality offer - should it set up nurseries? A related question is to which extent and in what areas municipalities should do business. It has become common for municipalities more or less to do business, i.e. they establish and run their own businesses that ensure clean public spaces, care for public greenery, construction work, etc. Even if we leave neoliberal views aside 
(which have no issues with municipalities acting as entrepreneurs), there is a wide range of activities that are discussed in terms of appropriateness for municipal entrepreneurship: should a municipality do business in forestry, should it run a communal shop, should it do business in the power engineering industry? Another topic can be housing policy - should the municipality own large numbers of flats and rent them, or should it make available only limited public housing? Conflict continues to rage over the privatization of flats (cf. Balík 2009: 224-225; Izi 2015). Another dimension of the debate opens up when discussion turns to what extent the municipality should support private entrepreneurship - for example, specific places such as the town Health clinic, which houses private doctors' offices (such a conflict basically completely changed the nature of local politics in the town of Bystřice nad Pernštejnem - cf. Mladá fronta Dnes 2005).

In other words, this is a question about the nature of public power at the local level - whether it should consist of minimal "services" dealing only with issues that cannot be resolved by the spontaneous activity of citizens, or whether it should play a role in social life in otherwise private spheres.

As mentioned above, the following four contradictions derive from national level cleavages that manifest at the local level and lead to the creation of political groups or parties, or at least temporary (ad hoc) alliances.

g) The religious contradiction - In this case, the distinction is not necessarily the most common one today, namely practising believers versus atheists, which is visible, for instance, in the question whether the municipality should financially contribute to the restoration of a church or small sacral structure. In the past, the Catholics versus Protestants conflict was locally more common, along with frictions between various Protestant denominations. In any case, the presence of KDU-ČSL in local administrations is the long-term visible representative of this cleavage.

h) Labour vs. capital - Topics related to the main contradiction of modern politics - the Gemeinschaft-Gesellschaft rift - are sometimes addressed at the local level; parties defined along this axis are the main alternatives to choose from in the local politics of larger cities. In the Czech context, this contradiction can manifest in the property tax debate. The municipality retains the entire yield from this levy, and it is the only tax the local authority can increase by raising the formula's coefficient (cf. Kruntorádová 2015: 86-87). Conflict also often arises over how communal waste disposal fees should be collected - e.g. whether it should be a merit-based or a solidarity-based system (cf. Balík 2009: 226).

i) The post-materialism contradiction - At the local level, this contradiction manifests most often in the area of environmental protection. However, in general terms it is a classical conflict between the themes of materialism and post-materialism, as well as a conflict amongst post-materialist themes. Society can be cleaved by questions such as: should priority be given to the renewal of marshlands, creating ponds, or repairing roads? This is the materialism versus post-materialism conflict. At the same time, a community can be deeply split with respect to the question whether the municipality should 
support a gay pride parade (see for example the political conflict over Prague Pride 2011 [Lidovky.cz 2015]), or how sexual education should be taught in public schools. Such questions arise not within the materialism versus post-materialism conflict, but as conflict amongst specific post-materialism positions.

j) The contradiction over relations to the old regime - The question of relationships to the former communist regime is still present in Czech municipalities. It can manifest through the existence of a communist party, but it can also manifest in relation to the nature of local governance in the pre-1989 communist system. Individuals who formerly were communist secretaries, chairmen and other representatives on pre-1989 national committees are still active in politics (although they are retreating from public life due to old age); there are municipalities that are still coming to terms with certain steps taken during the communist regime and various groups may have different opinions about this.

k) The gender contradiction - Although rare, this contradiction does exist in some municipalities and it is based on the differences between men and women. There are municipalities where the list of candidates is composed entirely of women or entirely of men (examples in 2010 included Brnírov, the Domažlice district; Jakubovice, the Šumperk district). Elsewhere, the contradiction manifests in a candidate list with a gender coloured name (whereas others have gender neutral names) - for example, the victorious "Women of Sobotín" of 2014 (Volby.cz 2015). As indicated earlier, this contradiction is not of a purely local nature. It is encouraged by European Commission policies such as gender budgeting, where the funds in public budgets are redistributed in such a way as to promote equal opportunities for men and women. Gender budgeting assesses the impact of a certain item on the life of men and women in all stages of the budgeting process. From this perspective, cancellation of certain bus services apparently affects more negatively women than men because women use public transportation more often. Another relevant example is the construction of a football stadium which has different benefits for women and men (compare Gender budgeting).

Not all types of cleavages exist in each and every municipality; in fact, this would be rather unlikely. An interesting question worth further research, though, is whether some cleavages could be conditioned by municipality size - whether some cleavages simply cannot manifest until the municipality reaches certain size. This could relate to the contradiction about the extent of municipality functions, where a small municipality has so few resources that it lacks funds for many things even if the will is there. So even though someone might want the municipality to set up a nursery or a school for their children, the whole debate can be quickly dismissed by pointing to budget constraints. It is also possible that in small municipalities, there is no room for the manifestation of post-materialist contradictions despite their possible existence.

Many local cleavages may have potential to manifest at the national level but they diminish or overlap with other contradictions due to the increasing level of aggregation nevertheless, they do manifest powerfully in smaller municipalities. 


\section{Conclusion}

Has politics got lost, or rather, is it disappearing from the local level? Certainly in the declaratory sense of the word, but in effect definitely not. It is "only" hidden or camouflaged, so it can even be argued that the electorate is manipulated. Under the veil of independence and non-partisanship the illusion of "non-interest" is promised.

Politics is being abandoned at the local level in other ways as well - for instance, by emphasizing anti-corruption efforts and transparency. This emphasis often (but not always) distracts from the meaningfulness of any given project, preventing us from considering whose interests are being served and how decisions are made; instead, we focus only on the transparency of the decision-making process and the subsequent expenses.

Local self-government is certainly a political level par excellence as the analysis of local cleavages shows. It may be possible to identify others. Thus, this is also an appeal for further research on and development of this topic, for which the author will be grateful.

\section{References}

BALÍK, Stanislav. 2004. Komunální politika: volby, aktéři, strategie. Př́padová studie okresu Šumperk od roku 1994. Ph.D. thesis, Department of Political Science, Faculty of Social Studies, Masaryk University, Brno.

BALÍK, Stanislav. 2009. Komunální politika. Obce, aktéŕi a cile místni politiky. Praha: Grada.

BUBENÍČEK, Václav and Michal KUBÁLEK. 2010. "Konfliktní linie v malých obcích.” Acta Politologica 3(2): 30-45.

BUBENÍČEK, Václav. 2009. “Doubice.” In Participace občanů na veřejném životě venkovských obcí $\check{C} R$, edited by Jaroslav ČMEJREK. Prague: Kernberg Publishing.

BURROW, John W. 2003. Krize rozumu. Evropské myšlení 1848-1914. Brno: CDK.

ČMEJREK, Jaroslav, Václav BUBENÍČEK and Jan ČOPÍK. 2010. Demokracie v lokálním politickém prostoru. Prague: Grada Publishing.

ČMEJREK, Jaroslav. 2005. "Specifika komunální politiky v malých obcích ČR.” Pp. 72-87 in Evropeizace. Nové téma politologického výzkumu, edited by Břetislav DANČÁK, Petr FIALA and Vít HLOUŠEK. Brno: International Institute of Political Science.

ČMEJREK, Jaroslav. 2008. Obce a regiony jako politický prostor. Prague: Alfa Nakladatelství.

ČMEJREK, Jaroslav. 2013. "Demokratický deficit v lokálním politickém prostoru ČR: možnosti a meze analýzy.” Acta Politologica 5(2): 178-186.

ČOPÍK, Jan. 2013. "Proměny lokálních politických mechanismů v prostředí české územní samosprávy." Acta Politologica 5(2): 125-142.

EIBL, Otto, Miloš GREGOR and Alena MACKOVÁ. 2013. Témata předvolebních kampaní v programech stran, jejich outdoorových kampaních a médiích. Pp. 65-91 in Krajské volby 2012, edited by Stanislav BALÍK et al. Brno: International Institute of Political Science.

FIALA, Petr and František MIKŠ. 2000. Rozhovory s Vladimirem Čermákem. O filosofii, politice a prá$v u$. Brno: CDK.

HLOUŠEK, Vít and Lubomír KOPEČEK. 2004. Konfliktni demokracie: moderní masová politika ve středni Evropě. Brno: International Institute of Political Science.

KRUNTORÁDOVÁ, Ilona. 2015. Politické aspekty financováni českých měst. Prague: Karolinum. 
KUBÁLEK, Michal and Václav BUBENÍČEK. 2012. “Charakter lokální politiky v suburbánním politickém prostoru." Acta Politologica 4(3): 284-305.

LIPSET, Seymour Martin and Stein ROKKAN. 1967. "Cleavage Structures, Party Systems, and Voter Alignments: An Introduction.” Pp. 1-64 in Party Systems and Voter Alignments: Cross-National Perspective, edited by Seymour Martin LIPSET and Stein ROKKAN. New York- London: The Free Press \& Collier-MacMillan Limited.

PŘIBÁŇ, Jiří. 2014. Obrana ústavnosti aneb Česká otázka v postnacionální Evropě. Prague: SLON.

RYŠAVÝ, Dan. 2006. "Komunální je komunální a velká je velká! K hypotéze politizace lokálních politických elit.” Sociologický časopis/Czech Sociological Review 42(5): 953-970.

VACHOVÁ, Jaroslava. 2010. Spolková činnost v Žarošicich. MA thesis. Department of History, Faculty of Arts, Masaryk University, Brno.

\section{Sources}

Act No. 128/2000 Coll., On Municipalities, as amended.

FOLTÁNKOVÁ, Kateřina and Anna FAJKUSOVÁ. 2014. "Nedvědice a Doubravník: Obyvatelé chtějí klid." Brněnský denik, August 20.

Genderové rozpočtování. Retrieved June 10, 2015 (http://padesatprocent.cz/cz/zpravodajstvi/genderove-rozpoctovani).

IZI. 2015. "Privatizace v Brně přijde draho lidi i magistrát. Chystají se žaloby." Retrieved June 10, 2015 (http://www.ceskatelevize.cz/ct24/regiony/307786-privatizace-v-brne-prijde-draho-lidi-i-magistrat-chystaji-se-zaloby/).

Lidovky.cz 2015. “Spor o pochod gayů štěpí ODS, Vysočina stojí za Klausem.” Retrieved June 10, 2015 (http://www.lidovky.cz/spor-o-pochod-gayu-stepi-ods-vysocina-stoji-za-klausem-p10-/zpravy-domov.aspx?c=A110811_142112_ln_domov_mev).

Město Lišov. Retrieved June 10, 2015 (http://www.lisov.cz).

Mladá fronta Dnes. 2005. "Novotný už není starostou Bystřice.", April 27, p. 1.

VEJROSTA, Pavel. 2014. "Slovo starosty.” Nedvědický zpravodaj 8(1): 1-3.

Volby.cz. 2015. Retrieved June 10, 2015 (http://www.volby.cz).

\section{Author}

Stanislav Balik is the head of the Department of Political Science at the Faculty of Social Studies, Masaryk University. He specializes in local politics, Czech ecclesiastical history and non-democratic regimes. He is the author of seven and the co-author of eight books (e.g. Komunální politika; Český antiklerikalismus 1848-1938, Katolická církev v Československu 1945-1989; Letnice 20. století; Postkomunistické nedemokratické režimy), of which two were also published in Germany and Poland, and many scientific papers published in domestic as well as international journals.

Contact: balik@fss.muni.cz 